NBER WORKING PAPER SERIES

\title{
INCOME AND THE USE OF PRESCRIPTION DRUGS BY THE ELDERLY: EVIDENCE FROM THE NOTCH COHORTS
}

\author{
John R. Moran \\ Kosali Ilayperuma Simon \\ Working Paper 11068 \\ http://www.nber.org/papers/w11068 \\ NATIONAL BUREAU OF ECONOMIC RESEARCH \\ 1050 Massachusetts Avenue \\ Cambridge, MA 02138 \\ January 2005
}

This work was supported by an unrestricted educational grant from The Merck Company Foundation, the philanthropic arm of Merck \& Co. Inc., awarded through Cornell University. We thank John Cawley, Gary Engelhardt, Bill Evans, Don Kenkel, Jeff Kubik, Sean Nicholson and seminar participants at Cornell University, Weill Medical College and the International Longevity Center for helpful discussions. The views expressed herein are those of the author(s) and do not necessarily reflect the views of the National Bureau of Economic Research.

(C) 2005 by John R. Moran and Kosali Ilayperuma Simon. All rights reserved. Short sections of text, not to exceed two paragraphs, may be quoted without explicit permission provided that full credit, including ( notice, is given to the source. 
Income and the Use of Prescription Drugs by the Elderly: Evidence from the Notch Cohorts John R. Moran and Kosali Ilayperuma Simon

NBER Working Paper No. 11068

January 2005

JEL No. I12, I18

\section{$\underline{\text { ABSTRACT }}$}

We use exogenous variation in Social Security payments created by the Social Security benefits notch to estimate how retirees' use of prescription medications responds to changes in their incomes. In contrast to estimates obtained using ordinary least squares, instrumental variables estimates based on the notch suggest that lower-income retirees exhibit considerable income sensitivity in their use of prescription drugs. Our estimates are potentially useful for thinking about the health care usage implications of any changes in transfer payments to the elderly that may occur in the future, and for evaluating the benefits of the recently enacted Medicare prescription drug benefit.

John R. Moran

Center for Policy Research

Syracuse University

426 Eggers Hall

Syracuse, NY 13244-1020

jmoran@maxwell.syr.edu

Kosali Ilayperuma Simon

Department of Policy Analysis and Management

Cornell University

106 MVR Hall

Ithaca, NY 14853

and NBER

kis6@cornell.edu 


\section{Introduction}

The affordability of prescription drugs has become an increasingly important issue for the elderly, who spend about a fifth of their income on health care ${ }^{1}$ (Crystal et al., 2000) and consume a disproportionate share of pharmaceuticals. Using data from 1996, Moxley et al. (2003) found that 88 percent of seniors used prescriptions medications during a 12 month period, with 58 percent taking three or more different drugs over the course of a year. Anecdotes concerning the use of potentially harmful cost-saving measures, such as foregoing medications, ad hoc dosing adjustments, and "pill splitting," have been widely reported in the popular press. Researchers have recently begun to investigate the prevalence of such practices, as well as their possible health consequences. Safran et. al (2002) found that nearly one in four low-income elderly, defined as those with incomes below 200 percent of the Federal Poverty Line, failed to fill a prescription due to cost concerns. Likewise, Piette et al. (2004) found that 16 percent of adults over age 50 taking medications for a chronic medical condition have skipped doses due to perceived cost pressures and, in the majority of cases, did so without conferring with their physician.

While the jury is still out on the health ramifications of patient-initiated reductions in prescription drugs, several recent studies suggest that cost considerations may have resulted in medically-harmful reductions in medication use among the elderly, particularly among those with lower incomes. Tamblyn et al. (2001) found that the imposition of cost-sharing for prescription drugs in the province of Quebec resulted in significant increases in hospitalizations, nursing home admissions, and mortality among elderly Canadians who cut back on their medication use in response to the newly-enacted cost-sharing provisions. Similarly, Heisler et al. (2004) document a greater likelihood of declines in self-reported health among the elderly and near elderly with cost-related medication reductions, as well as higher rates of angina, heart 
attacks and strokes among patients with cardiovascular disease who reduced their drug utilization due to concerns about cost.

Despite its significance for a variety of public policy issues, ${ }^{2}$ little is known about how income influences prescription drug use. Most research has instead focused on the impact of cost-sharing provisions in supplemental insurance plans (see, for example, Federman et al., 2001). ${ }^{3}$ A recent exception is a study by Stuart and Grana (1998) who surveyed 4000 Medicare beneficiaries in Pennsylvania. They found that Medicare beneficiaries with annual incomes above $\$ 18,000$ were 18 percent more likely than those with incomes below $\$ 6000$ to use prescription drugs to treat their health conditions. Similarly, Kassab et al. (1996) found that rural Medicare beneficiaries with lower incomes were less likely to visit dentists than higher-income beneficiaries, but that income was not correlated with hospital use. Finally, in a study of the non-elderly employed population, Newhouse and Phelps (1974) found that the demand for health care services rose with wage income, but not with non-wage income. They noted, however, that an inability to fully control for health status may have biased their estimates downward due to the possible correlation between income and health.

A fundamental challenge faced by such studies is isolating the underlying causal relationship between income and prescription drug use from a large number of inherently unobservable characteristics that likely influence both an individual's lifetime earnings (and therefore the amount of income available after retirement), and their propensity to use prescription medications. For instance, individuals differ in the extent to which they discount the future, with those placing a higher value on current consumption being less likely to accumulate financial and human capital, leaving them with lower incomes during retirement. Given their higher discount rates, such individuals may also be less willing to forgo current consumption to 
purchase prescription drugs, whose benefits often accrue in later years. ${ }^{4}$ Thus, absent an ability to adjust for differences in discount rates, an ordinary least squares (OLS) regression would produce an upward bias in the estimated relationship between prescription drug utilization and income.

Other unobservable factors, such as differences in risk aversion or health status, would likely result in a downward bias. For example, more risk-averse individuals are less likely to sort into riskier, and therefore, higher paying, jobs. ${ }^{5}$ Such individuals are also less likely to invest in riskier assets which, on average, generate higher returns. At the same time, more risk-averse individuals would presumably be more prone to use prescription drugs, all else equal, as a means of safeguarding their health. Thus, failing to account for differences in risk preferences would lead to a downward bias in the estimated relationship between income and prescription use. Finally, because it's difficult to fully control for differences in health using standard survey data, a downward bias in the estimated income elasticity will occur if those in poorer health use more prescription medications and earned (or saved) less during their working life than healthier individuals.

In this paper, we seek to circumvent these endogeneity problems by relying on a natural experiment that generated large, exogenous differences in Social Security payments for otherwise identical individuals based on their year of birth. The aptly-named Social Security benefits "notch," which we detail in the next section, came about as a result of an error in the manner in which payments to beneficiaries were indexed for inflation, coupled with a subsequent modification of the benefits formula to correct the initial error. The large differences in benefits occasioned by these changes in the Social Security law have been used by others to estimate the effect of income on retirement behavior (Krueger and Pischke, 1992), mortality (Snyder and 
Evans, 2002), elderly living arrangements (Engelhardt, Gruber and Perry, forthcoming) and elderly poverty rates (Engelhardt and Gruber, 2004).

Using data from the 1993 wave of the Study of Asset and Health Dynamics Among the Oldest Old (AHEAD), we find small and statistically insignificant effects of income on prescription drug use when Social Security payments are treated as exogenous. However, when the benefits notch is used as an instrument for Social Security income,${ }^{6}$ a larger and statistically significant effect of income on drug utilization emerges for households headed by beneficiaries with less than a high school education (approximately 44 percent of our sample). We were unable to obtain estimates for more-educated retirees because the notch instrument does not yield a sufficiently strong first-stage relationship to permit a valid inference for these households. ${ }^{7}$ Nonetheless, it seems plausible that the large income effects we find for less-educated households may apply more generally.

Our estimates indicate that a $\$ 1000$ increase in post-retirement income (in 1993 dollars) for those in our low-education (lower-income) group would increase the number of prescription medications used in a typical month by approximately 0.55 prescriptions per household. Evaluated at the mean levels of drug utilization and Social Security income in the low-education sample, this translates into an elasticity of roughly 1.32, suggesting that lower-income retirees exhibit considerable income sensitivity in their use of prescription drugs. Thus, to the extent that future retirees can be expected to behave like earlier cohorts, one would anticipate that reductions in Social Security benefits (or other policy changes that affect retirement incomes, such as increases in Medicare premiums) would significantly reduce prescription drug use among lower-income beneficiaries, and possibly among those with higher incomes as well. 
The paper proceeds as follows. In Section 2, we provide a brief overview of the Social Security benefits notch and how it has been used to identify income effects in other settings. In Section 3, we discuss our data and empirical strategy. In section 4, we present our main results, along with a series of specification checks. Concluding remarks are offered in Section 5.

\section{The Social Security Benefits Notch}

Detailed accounts of the legislation that led to the benefits notch, as well as the specifics of how Old Age and Survivor's Insurance (OASI) benefits are calculated, can be found in all of the existing papers that have made use of the notch (Krueger and Pischke, 1992; Snyder and Evans, 2002; Engelhardt, Gruber and Perry, forthcoming). Here, we provide a general overview, referring the reader to the papers listed above for a more in depth discussion. ${ }^{8}$

Prior to 1972, Social Security benefits were calculated using nominal earnings histories, truncated at the covered earnings maximum for each year. A formula was applied to each worker's Average Monthly Earnings (AME) to determine the Primary Insurance Amount (PIA), which was equal to the worker's monthly benefit if they retired at age 65; if they retired earlier, the monthly benefit was reduced to reflect the longer period over which payments would be made. The formula used to calculate the PIA was based on a set of earnings brackets and an associated earnings replacement rate within each bracket that declined as higher brackets were reached.

To protect retirees from the effects of inflation, Congress periodically adjusted benefits, enacting large increases in 1967, 1969, 1971 and 1972. In 1972, Congress amended the Social Security Act to provide automatic indexation for workers who had not yet retired. The 1972 Amendments inadvertently conferred a windfall on these workers by continuing to use nominal 
wages in the calculation of AME, while at the same time indexing the replacement rates used to convert AME into monthly benefits. By combining a nominal wage, which grows with inflation, with an indexed benefits formula, the 1972 Amendments created a stream of payments to future retirees that were doubly indexed, and therefore more generous than intended. ${ }^{9}$ The high rates of inflation that occurred shortly thereafter resulted in large increases in benefits for individuals born after 1907, creating a potential threat to the solvency of the system.

In 1977, in response to a rapid escalation in benefit costs brought on by this error, Congress again amended the Social Security Act. The 1977 Amendments eliminated double indexation by replacing the nominal wages used in the calculation of AME with an indexed (real) wage, termed Average Indexed Monthly Earnings (AIME). Importantly, workers near retirement in 1977 (those born prior to 1917) retained doubly-indexed benefits under a grandfather provision. This created a sizeable reduction in benefits for those born in 1917 or later, relative to earlier cohorts. ${ }^{10}$ Other changes to the law, including increases in the covered earnings maximum, led to a resumption of the upward trend in real benefits for those born after $1921^{11}$

Set against a gradual upward trend in benefits for successive birth cohorts, the rapid runup in benefits created by double indexation, coupled with the abrupt decline in benefits mandated by the 1977 Amendments, generated what has come to be known as the Social Security "benefits notch," depicted in Figure 1. ${ }^{12}$ As others have noted, the differences in benefits engendered by these changes in the Social Security Act were both large and unanticipated, making them well suited for the analysis of income/wealth effects among the elderly. ${ }^{13}$

The subsequent upward trend in benefits was substantially more pronounced for those with higher incomes because an increase in the covered earnings maximum resulted in a 
differential increase in the fraction of earnings subject to Social Security taxes for high-income workers relative to low-income workers. Thus, when looking at real benefit levels across birth cohorts, the size of the benefits notch created by double indexation is much larger for lowerincome retirees than for higher-income retirees due to the offsetting increase in benefits for the high-income group arising from the higher earnings cap. Because our instrumental variables approach compares retirees from the birth cohorts who received unusually high benefits (due to double indexation) to retirees with more typical benefits from adjacent cohorts, any flattening of the associated benefits notch weakens our first-stage regressions. This attenuation in the benefits differential across our "treatment" and "control" groups precludes us from obtaining reliable estimates for better-educated (higher-income) households, but yields a strong first-stage relationship, and precise parameter estimates, when the roughly 44 percent of households with less than a high-school education are considered.

It is worth noting that there are many alternative ways of using changes in the Social Security law to identify income effects and different researchers have adopted different approaches. In the first paper to use the benefits notch as a source of exogenous variation in retirement incomes, Krueger and Pischke (1992) exploited the fact that the 1977 Amendments created a pronounced break in an otherwise upward trend in the real value of benefits to test whether the trend toward earlier retirement was causally linked with rising Social Security benefits. The absence of a reversal in this trend for the 1917-1921 birth cohorts, who experienced a large, permanent reduction in their Social Security wealth relative to other retirees born between 1901 and 1930, suggests that rising Social Security benefits most likely did not play a causal role in hastening retirement. By contrast, Snyder and Evans (2002) focus more narrowly on the notch years by comparing mortality rates among individuals who differed only by a 
quarter of birth; specifically, those born in the fourth quarter of 1916 (the approximate peak of the notch) relative to those born in the first quarter of 1917. They find that, in contrast to the conventional wisdom on the subject, an increase in income during retirement leads to higher mortality rates, possibly due to greater activity and reduced social isolation on the part of those with reduced incomes.

Our approach is closest to that of Engelhardt, Gruber and Perry (forthcoming), who compare the living arrangements of those who experienced relatively high Social Security incomes with surrounding birth cohorts from 1900 to 1933 whose real Social Security benefits were lower. ${ }^{14}$ They find that the propensity of elderly individuals to live in shared living arrangements is inversely related to income, and that this effect is concentrated among lowerincome retirees, which they proxy for using differences in education. In the next section, we describe our data and identification strategy in more detail.

\section{Data and Empirical Strategy}

\subsection{General Issues}

One practical difficulty with using the benefits notch to study prescription drug use is that most of the variation in Social Security income induced by the notch applies to birth cohorts centered around 1916, making it difficult to locate data sources with information on prescription drug use that also contain a large enough sample of "notch babies" to yield reasonably precise estimates. The only publicly-available data source (of which we are aware) that meets these and other desirable criteria is the Study of Assets and Health Dynamics Among the Oldest Old (AHEAD), a companion survey to the better known Health and Retirement Study. ${ }^{15}$ Aside from the AHEAD data, the only other dataset that was potentially useful for our purposes was the 
Consumer Expenditure Survey (CEX). There were, however, two considerations which argued in favor of using the AHEAD. First, unlike the AHEAD, the CEX is based on a random sample of the entire population, so one would have to rely heavily on data from the late 1970s and early 1980s to capture a significant number of individuals born during the notch and surrounding years. Second, the CEX provides data on drug expenditures (not quantities), which are often filtered through supplemental health insurance policies of varying generosity. Thus, if two households were to experience the same exogenous increase in Social Security income, one might opt to purchase additional prescriptions directly, while the other might do so indirectly by purchasing a more generous Medigap policy, or by upgrading to a policy that contains drug coverage from one that does not. Though both households may be equally responsive to changes in their income, one would appear to have a more elastic response if out-of-pocket spending were used as the utilization measure. In contrast, the AHEAD asks respondents about the number of prescription medications taken during a typical month, thereby allowing us to estimate the total effect of an increase in Social Security income on prescription drug utilization, taking both of the aforementioned channels into account. ${ }^{16}$

\subsection{Data}

The AHEAD is a longitudinal survey of individuals aged 70 or older in 1993 and their spouses (regardless of age). The first wave of the AHEAD, fielded in 1993, provides extensive information on 8,222 individuals in 6,047 households on items such as their demographic characteristics, income, wealth, employment status, health status, insurance holdings, and utilization of medical care. Some questions were asked of only one household member, but were designed to apply to the household as a whole, while others were asked of each household member separately. African Americans, Hispanics, and residents of the state of Florida were 
over-sampled, with sample weights available to adjust for this and other non-representative elements of the sample design. A response rate of just over 80 percent was obtained in the first wave of the survey. One follow-up survey was conducted in 1995 and the surviving AHEAD respondents were integrated into the HRS in 1998.

Although the AHEAD is structured longitudinally, we were unable to take advantage of this feature in our work because respondents were only asked about the number of prescription drugs they use in the first wave of the survey. The drug questions that were repeated in later waves either pertain to out-of-pocket spending, which is difficult to interpret for the reasons discussed earlier, or are discrete outcomes that didn't exhibit sufficient variation to generate estimates with any reasonable degree of precision; e.g., whether the respondent took any prescription medicines versus none.

\subsection{Estimation Sample}

The unit of observation for our analysis is the household because it seems likely that married or cohabiting individuals pool resources and make joint decisions when it comes to purchasing items like prescription drugs. Approximately 46 percent of our sample is made up of two-person households (in the vast majority of cases, a husband and a wife), with 54 percent of households having only one member.

Our first task is to designate a primary Social Security beneficiary for each household. We do so for two reasons: (1) to determine which households were likely to have benefited the most from double indexation (an indicator of which serves as our instrument); and (2) to split the sample based on the educational attainment of the primary beneficiary, which turns out to be important for our estimation strategy. 
In so doing, we follow previous work in designating the male member of two-person households as the primary Social Security beneficiary, omitting a small number of cases in which the female is the only household member who reports receiving benefits. ${ }^{17}$ Thus, for all households containing a male member, we use the male's year of birth to assign the household to either the treatment or control group. ${ }^{18}$ Households with no male members can be divided into two categories: never-married females and widowed/divorced females. In the case of nevermarried females, we designate the female as the primary beneficiary and use her year of birth to determine treatment-control status for the household. In the case of widowed/divorced females, we designate the deceased or former husband as the primary beneficiary and follow Engelhardt, Gruber and Perry (forthcoming) in subtracting three years from the female's year of birth to generate a birth year for the deceased/former husband, which is then used to assign the household to either the treatment or control group. ${ }^{19}$

In creating our estimation sample, we restrict attention to the birth cohorts studied by Krueger and Pischke (1992); namely, households whose assigned Social Security beneficiary was born between 1901 and 1930. We also drop a small number of households that report no Social Security income, or that report Social Security income of less than $\$ 100$ per month (in 1993 dollars). ${ }^{20}$ These restrictions, coupled with observations lost from missing or incomplete data, yield a final sample of 4,007 households.

\subsection{Empirical Specification}

To estimate the impact of Social Security income on prescription drug use, we estimate equations of the form shown below.

$$
D_{h}=\alpha+\beta \text { SSIncome }_{h}+\delta \mathbf{X}_{h}+\varepsilon_{h}
$$


where $h$ indexes households. $D_{h}$ is the typical number of prescription medications that each household uses in a month, SSIncome ${ }_{h}$ is annual household Social Security income (measured, for ease of interpretation, in thousands of 1993 dollars), $\mathbf{X}_{h}$ is a vector of control variables and $\varepsilon_{h}$ is the error term. The coefficient on household Social Security income, $\beta$, measures how a one thousand dollar increase in annual Social Security income affects the number of prescription drugs each household uses in a typical month. $\mathbf{X}_{h}$ includes a standard set of demographic variables for each household: indicator variables for the type of household (male head - married or cohabiting; male head - single; female head - never-married; female head - widowed; and female head - divorced), age of the head, race of the head (white, African American, or other), Hispanic ethnicity of the head, whether the household is located in an MSA, and location (indicators for each of the nine Census regions). ${ }^{21}$

Other variables, such as measures of health status or insurance coverage, are not included as controls because they represent additional outcome variables that are likely to be affected by changes in Social Security income, including changes induced by the benefits notch. ${ }^{22}$ As a result, $\beta$ provides an estimate of the total effect of a change in income on prescription drug use, incorporating all of the behavioral responses precipitated by the income change, e.g., changes in labor force participation, health status, or insurance coverage. From a policy perspective, one would want this type of estimate - one which takes all of the aforementioned adjustments into account, rather than holding them constant - when calculating the likely impact of a change in income on drug utilization. ${ }^{23}$

Equation (1) will be estimated twice for each model specification; first by ordinary least squares and second using an instrumental variables estimator that accounts for the endogeneity of income. The first-stage regression is displayed in equation (2) below. 


$$
\text { SSIncome }_{h}=\gamma+\theta \text { Notch }_{h}+\phi \mathbf{X}_{h}+u_{h}
$$

Our instrument, labeled Notch $_{h}$, is an indicator variable that takes the value "one" for households whose primary Social Security beneficiary was born during the notch years of 1915-1917, and "zero" for households whose primary beneficiary was born in any other year between 1901 and 1930. The years 1915-1917 were selected because they represent the peak of the benefits notch and provide the strongest first-stage relationship between Social Security income and notch status for the cohorts in our sample.

Table 1 provides descriptive information on the main variables used in our analysis, separated into two sub-samples based on the educational attainment of the primary Social Security beneficiary: 1,755 households whose primary beneficiary had less than a high school education and 2,252 households whose primary beneficiary had a high school diploma or better. $^{24}$

As mentioned previously, respondents were only asked about the number of prescription drugs they use in the first wave of the survey. This is potentially problematic because the benefits notch is based on year of birth, which is perfectly correlated with age in a single cross section of individuals. Previous studies have addressed this problem either by relying on extremely large datasets to compare individuals that differ only slightly in age (Snyder and Evans, 2002), or by exploiting age by year-of-birth variation (Krueger and Pischke, 1992; Engelhardt, Gruber and Perry, forthcoming; Engelhardt and Gruber, 2004).

Because we have a relatively small number of observations, and do not have age by yearof-birth variation in the data, we attempt to address this issue by showing that our results are not sensitive to the inclusion of a progressively more flexible specification of the age variable; in particular, we enter age as a polynomial function whose order ranges from one (linear) to three 
(cubic). ${ }^{25}$ It is also worth noting that the average age among those receiving higher Social Security benefits due to the notch (our treatment group) is lower than the average age of those in adjacent cohorts (our control group). Thus, if younger households are healthier on average, any residual effects of age not captured by our age variables should impart a downward bias to the estimated relationship between Social Security income and prescription drug use.

A related concern is that there may be pure "cohort effects" in drug utilization that potentially confound the treatment-control comparison groups we have formed. Two such possibilities are the long-term repercussions of in utero exposure to the influenza virus in late 1918 and early 1919 (Almond, 2003), as well as the more general worry that using cohorts that are sufficiently far apart in time could render the estimates susceptible to biases from any unobserved differences between cohorts. In the next section, we provide some suggestive evidence that these types of cohort effects are not driving our results. First, we show that removing the "flu babies" from our sample, the most obvious source of a systematic difference in drug utilization across birth cohorts, has virtually no impact on our estimates. And second, we show that restricting attention to a narrower, and presumably more comparable, set of birth cohorts (those born between 1910 and 1920) also does not greatly affect our results.

\subsection{Effect of the Notch by Education Group}

As was discussed in detail earlier, the impact of the benefits notch varies substantially based on income/education. This difference is evident in Table 2, where separate estimates of equation (2) are presented based on the educational attainment of the primary Social Security beneficiary. In each case, three model specifications are estimated to examine the sensitivity of our findings to alternative methods of controlling for the effects of age. All specifications include the full set of demographic variables described in the previous section and all are weighted using 
the AHEAD household weights. We adjust our (robust) standard errors for clustering on birth year.

For the low-education (lower-income) group, having been born at the peak of the notch years (1915-1917) increases household Social Security income by between $\$ 1,000$ and $\$ 1,400$ per year in 1993 dollars. Relative to a mean household Social Security income of $\$ 9,625$ for this group, this translates into an increase of between 10 and 14.5 percent. These regressions provide a strong first-stage for our IV estimation strategy, with partial F-statistics for the notch indicator ranging from 16.80 to 33.18 in our baseline specification, well above the threshold cited by Staiger and Stock (1997) for establishing bias due to weak instruments.

By contrast, the relationship between notch status and Social Security income is much weaker for households whose primary beneficiary has a high school diploma or better. For these households, having been born during the notch years only increases household Social Security income by between $\$ 72$ and $\$ 301$ per year, corresponding to a percentage increase of between 0.6 and 2.7 percent when evaluated at the mean household Social Security income for this group $(\$ 11,085)$. Moreover, the partial F-statistics from these regressions are all below 1.00, suggesting that there is not a strong enough first-stage relationship present to support an IV estimation strategy for this group. ${ }^{26}$

As a result, we focus on the 1,755 households from the low-education sub-sample (approximately 44 percent of the full sample) to obtain estimates of the effect of income on prescription drug utilization. It should be emphasized that what we refer to as the "loweducation" group, those with less than a high school diploma, is far more representative of the population as a whole than would be the case today. For example, Goldin (1999), who analyzed trends in education in the early part of the $20^{\text {th }}$ century, found that the rate of high school 
completion (relative to the population of 17 year olds in that year) was just 13 percent in 1915 and was only 41 percent as late as $1935 .^{27}$

\section{Results}

\subsection{Baseline Estimates}

Our main estimates of the effect of income on prescription drug utilization are presented in Table 3. Looking across the three age specifications, we find small and statistically insignificant effects of income on the number of prescriptions used by each household when these effects are estimated by ordinary least squares. By contrast, when the benefits notch is used as an instrument for household Social Security income, we find large and statistically significant effects of income on drug use across all three model specifications, with the magnitude of the income effect rising a bit as tighter controls for age are incorporated. Focusing on the quadratic age specification, our coefficient estimate indicates that a $\$ 1000$ increase in Social Security income (in 1993 dollars) would increase the number of prescription medications used in a typical month by approximately 0.55 per household. Evaluated at the mean levels of drug utilization and Social Security income in the sample (shown in Table 1 ), ${ }^{28}$ this translates into an elasticity of approximately 1.32, implying a high degree of income sensitivity on the part of lower-income retirees.

Given that notch households receive higher Social Security payments than households from adjacent cohorts, it follows that if higher incomes do in fact increase prescription use, a reduced-form relationship between the benefits notch and prescription drug utilization should emerge. In particular, this relationship will exist regardless of which income measure is used in the construction of the IV estimates, thus providing a means of examining whether our use of the 
more reliably reported Social Security income measure has generated a spurious finding that would not have emerged if total household income had been used in its place. In Table 4, we present estimates of this reduced-form relationship, finding that households whose primary Social Security beneficiary was born during the notch consume approximately 0.60 more prescription medications in a typical month than households whose primary beneficiary was born in adjacent (non-notch) years. The estimated effect of notch status on drug use is quite similar across the three age specifications and is statistically significant at better than the 0.01 level in each case.

\subsection{Exclusion of Widows and Divorced Females}

In assigning a birth year to households headed by divorced or widowed females, it was necessary to rely on the assumption that the former husbands of these women were born three years earlier than their wives, three years being the median difference in spousal ages for divorced and widowed elderly in 1982 (Engelhardt, Gruber and Perry, forthcoming). Although this assumption would appear to be innocuous, in Table 5 we provide a quick check by reestimating equation (1) with these households omitted from the sample. Because the results are quite similar to those from Table 3, we retain these households to enhance the precision of our estimates when conducting specification checks that require the use of a smaller sample.

\subsection{Cohort Effects}

To examine the sensitivity of our results to possible cohort effects, we focus on two that seem especially plausible. The first involves individuals born during 1918 and 1919, who may have had in utero exposure to the flu virus that was present in epidemic proportions during those years. Almond (2003) presents evidence that such individuals may suffer from poorer health throughout their lives, suggesting that our instrument may be correlated with unmeasured 
differences in prescription drug utilization. We investigate this possibility by dropping those households whose primary Social Security beneficiary was born during the flu years of 1918 and 1919. Results from this sensitivity check, which are displayed in Table 6, indicate little change relative to our baseline estimates.

A more general issue relates to the overall comparability of our treatment and control groups, given that our control group is made up of households whose primary beneficiaries were born over a period spanning 30 years. As one compares the notch households to households that are further removed in time, the likelihood of there being systematic differences in prescription drug use, for reasons unrelated to (notch-induced) differences in Social Security income, increases.

We examine this possibility by re-estimating equation (1) using only those households whose primary Social Security beneficiary was born between 1910 and 1920, reducing by almost two decades the range of cohorts being compared. As can be seen from Table 7, restricting attention to a narrower range of birth cohorts slightly increases the estimated effect of Social Security income on prescription use in our IV regressions (and this effect remains statistically significant at conventional levels), while the OLS estimates are once again small and statistically insignificant.

The findings presented in this section obviously cannot completely exclude the possibility of confounding due to unobserved differences across birth cohorts. However, for such effects to compromise our results they would have to vary systematically across our treatment and control groups. Two plausible sources of systematic differences in prescription use across the notch and non-notch cohorts were examined and were not found to dramatically affect 
our estimates. Nonetheless, the potential existence of biases related to such cohort-based effects should be kept in mind when considering our results.

\subsection{Additional Variation in Social Security Benefits}

As discussed in Section 2, there are many way in which the benefits notch can be used to identify the effect of income on the behavior of the elderly. We have opted for a simple "highlow" comparison because it provides a particularly sharp difference in incomes across birth cohorts, as evidenced by the strong first-stage relationship between Social Security income and the notch indicator. However, this approach ignores year-to-year variation in benefits that affected the cohorts under study, many of which can be attributed to other changes in the Social Security law. To examine the robustness of our estimates to these additional sources of variation (e.g., the ad hoc changes in benefits that preceded automatic indexation), we make use of the synthetic benefits instrument created by Engelhardt, Gruber and Perry (forthcoming). A brief summary of their instrument follows; for a more detailed account, the reader is referred to their paper.

The Engelhardt, Gruber and Perry (EGP) synthetic benefits instrument utilizes all yearto-year variation in legislated Social Security benefits, holding real earnings constant. It is calculated using a program that applies all of the legislated changes in Social Security benefits that affected each birth cohort to a fixed earnings history - the median earnings profile of a male worker born in 1916 (roughly the midpoint of the sample). Thus, by construction, their synthetic benefits schedule yields an average benefit (by birth year and level of education) that omits any differences in benefits attributable to household characteristics. It differs from our instrument, which makes use of a single treatment group, by comparing exogenous differences in benefit generosity across each birth cohort in the sample. In contrast to our simpler "high-low" 
comparison, it makes use of more sources of variation, but relies on smaller differences in Social Security payments for identification. This was a logical approach for EGP because, given the size of their sample, these small differences could be measured with a high degree of precision. In our case, this approach is potentially problematic due to the relatively small number of households within each birth cohort. As a result, we believe that our most reliable estimates are those presented in Table 3; however, it is reassuring that exploiting these additional sources of variation in Social Security benefits yields similar estimates. In addition, because the EGP instrument mechanically eliminates differences in earnings histories across birth cohorts, it is less vulnerable to confounding from unobserved cohort effects, and therefore provides another means of checking our baseline estimates for bias from this source.

Table 8 presents the results of re-estimating equation (1) using the EGP synthetic benefits schedule as an instrument for the actual Social Security benefits reported by the households in the AHEAD sample. ${ }^{29}$ To make the first-stage relationship more transparent, we updated the EGP synthetic benefit schedule, which was measured in 1982-1984 dollars, to 1993 dollars using

the CPI calculator on the BLS webpage. ${ }^{30}$ As shown in Table 8 , when age is measured linearly, the EGP instrument delivers a second-stage coefficient estimate that is virtually identical to what we found using the notch indicator (Table 3). When age is entered as a quadratic or cubic function, the EGP instrument also generates estimates that are quite similar to those produced by our instrument, albeit slightly larger.

\subsection{Count Data Specification}

As a final robustness check, we examine the possibility that our second-stage equation may be misspecified due to the fact that our dependent variable is measured as a count (number of prescriptions). In the absence of zeros, the Poisson regression model can be transformed into a 
log-linear regression by imposing a logarithmic transformation to both sides of the regression equation; this transforms the right-hand side of the model from one with an exponential regression function and a multiplicative error to one with a linear regression function and an additive error. Mullahy (1997) notes that applying standard linear instrumental variables techniques to the transformed equation yields consistent estimates of the second-stage coefficients. While such an approach is viable, strictly speaking, only in the absence of zeros, we have adopted it here as a simple specification check because only 3.5 percent of the observations in our sample are comprised of zero counts.

In Table 9, we proceed by dropping these observations and re-estimating equation (1) using a log-linear specification in conjunction with our notch instrument; however, we retain the zero counts when attempting to replicate our earlier OLS results using a standard Poisson model. Because the coefficient estimates are scaled differently in the Poisson and log-linear models than in a linear model, it is easiest to compare the associated income elasticity estimates from Table 9 to those in Table 3. Such a comparison reveals identical elasticity estimates when the OLS regressions from Table 3 are re-estimated as Poisson models in Table 9. Likewise, the log-linear IV elasticity estimates in Table 9 are similar, albeit a bit smaller, to the linear IV estimates from Table 3. The broad similarity of both sets of estimates suggests that treating the dependent variable as continuous is unlikely to have greatly affected our results.

\section{Conclusions}

In this paper, we made use of a unique natural experiment that led otherwise identical retirees to receive substantially different payments from the Social Security system. The benefits notch is unique in that it constitutes the only break in an otherwise upward trend in the real value 
of benefits in the history of the Social Security program. By comparing those households that enjoyed artificially high benefits (the so-called notch cohorts) to adjacent cohorts whose benefit levels were lower, ceteris paribus, we were able to construct instrumental variable estimates of the income sensitivity of prescription drug use among lower-income retirees.

We find that a $\$ 1000$ increase in post-retirement income (in 1993 dollars) would increase the number of prescription medications used by lower-income elderly households by approximately 0.55 prescriptions per household. Evaluated at the mean levels of drug utilization and Social Security income for this group, this translates into an elasticity of roughly 1.32 . These estimates contrast sharply with the small and statistically insignificant effects one obtains when Social Security income is treated as exogenous. Although we were not able to obtain estimates for retirees with higher incomes, the large elasticities we found for the 44 percent of elderly households belonging to our low-education (lower-income) sample is suggestive of some degree of income sensitivity among retirees further up the income distribution.

Given that Social Security comprises a larger share of total income for lower-income households, and given that these households are generally considered to be the most vulnerable to economic and health shocks, the large income effects we found for this group are potentially important when considering policy changes that affect transfer payments to lower-income elderly, such as changes in Social Security benefits or Medicare premiums, as well as for assessing the extent to which the new Medicare drug benefit will shield lower-income retirees from income-induced changes in their use of prescription medicines. ${ }^{31}$ Moreover, because approximately 59 percent of the households in our low-education (lower-income) sample would still face significant cost sharing for prescription drugs under the new Medicare law, our results bear directly on how future changes in Social Security are likely to affect their drug utilization, 
and possibly, the drug utilization of somewhat higher-income beneficiaries for whom our estimates may also be applicable.

In closing, a few potential limitations of our empirical approach should be noted. First, because we did not have age by year of birth variation in our data, we were not able to control for the independent effects of age in a fully flexible way (i.e., by using a full set of age dummies). Instead, we modeled the effects of age using progressively higher-order polynomials and found that our results were not particularly sensitive to the choice of a functional form for the age variable. Second, because the Social Security notch varies by birth cohort, there is no way to definitively control for pure cohort effects in the use of prescription drugs or other variables. However, to bias our results, any unobserved cohort-level effects would have to vary systematically across our treatment and control groups, and two specification checks based on plausible sources of cohort-based effects did not produce large departures from our initial estimates, nor did the use of a synthetic benefits instrument which, by construction, eliminated any differences in lifetime earnings across birth cohorts. These limitations notwithstanding, the changes in Social Security income created by the benefits notch provide a rare opportunity to utilize plausibly exogenous variation in retirement incomes for the purpose of estimating the income sensitivity of prescription drug use among a population of significant policy interest. 


\section{References}

Almond, Douglas (2003) "Is the 1918 Influenza Pandemic Over? Long-Term Effects of In Utero Influenza Exposure in the Post-1940 U.S. Population," Working Paper, University of California at Berkeley.

Altman, Drew (2004) “The New Medicare Prescription Drug Legislation,” New England Journal of Medicine 350, 9.

Crystal, S. R.W. Johnson, J. Harman, U. Sambamoorthi and R. Kumar (2000) "Out-of-Pocket Health Care Costs among Older Americans," Journal of Gerontology Series B: Psychological Sciences and Social Sciences 55, S51-S62.

Engelhardt, Gary and Jonathan Gruber (2004) "Social Security and the Evolution of Elderly Poverty,” NBER Working Paper No. 10466.

Engelhardt, Gary, Jonathan Gruber and Cynthia Perry (forthcoming) "Social Security and Elderly Living Arrangements: Evidence from the Social Security Notch," Journal of Human Resources.

Evans, William, Jeanne Ringel and Diana Stech (1999) "Tobacco Taxes and Public Policy to Discourage Smoking," in Tax Policy and the Economy 13, James Poterba, editor. Cambridge, MA.: National Bureau of Economic Research.

Fuchs, Victor (1982) "Time Preferences and Health: An Exploratory Study," in Economic Aspects of Health, Victor Fuchs, editor. Chicago: University of Chicago Press.

Goldin, Claudia (1999) "A Brief History of Education in the United States," NBER Working Paper, Historical Series No. 119.

Heisler, M., Kenneth Langa, Elizabeth Eby et al. (2004) "The Health Effects of Restricting Prescription Medication Use Because of Cost," Medical Care 42, 626-634.

Kassab, C., A.E. Luloff, T.W. Kelsey and S.M. Smith (1996) "The Influence of Insurance Status and Income on Health Care Use among the Non-Metropolitan Elderly," Journal of Rural Health 12, 89-99.

Kenkel, Donald (1991) "Health Behavior, Health Knowledge, and Schooling," Journal of Political Economy 99, 287-305.

Krueger, Alan and Jorn-Steffen Pischke (1992) "The Effect of Social Security on Labor Supply: A Cohort Analysis of the Notch Generation," Journal of Labor Economics 10, 412-437.

Moxley, E., J.P. O’Connor, K.D. Noveielli, S. Teutsch and D.B. Nash (2003) "Prescription Drug Use in the Elderly: A Descriptive Analysis," Health Care Financing Review 24, 127-141. 
Mullahy, John (1997) "Instrumental Variable Estimation of Count Data Models: Applications to Models of Cigarette Smoking Behavior," Review of Economics and Statistics 79, 586593.

Newhouse, Joseph P. and Charles E. Phelps (1974) "Price and Income Elasticities for Medical Care Services." In The Economics of Health and Medical Care: Proceedings of a Conference of the International Economics Association, ed. Shigeto Tsuru and Mark Perlman. London: Macmillan. Also available from Santa Monica: RAND Corporation (Pub. no. R-1197-NC).

Piette, John, Michele Heisler and Todd Wagner (2004) "Cost-Related Medication Underuse: Do Patients with Chronic Illnesses Tell Their Doctors?" Archives of Internal Medicine 164, 1749-1755.

Safran, Dana Gelb, Patricia Neuman, Cathy Schoen, et al. (2002) "Prescription Drug Coverage and Seniors: How Well Are States Closing the Gap?" Health Affairs, Web Exclusive, W253-W268.

Social Security Administration (2004) Annual Report of the Board of Trustees of the Federal Old-Age and Survivors Insurance and Disability Insurance Trust Funds, available online at: http://www.ssa.gov/OACT/TR/TR04/index.html

Snyder, Stephen and William Evans (2002) "The Impact of Income on Mortality: Evidence from the Social Security Notch,” NBER Working Paper \# 9197.

Staiger, Douglas and James H. Stock (1997) "Instrumental Variables Regression with Weak Instruments," Econometrica 65, 557-586.

Stuart, B. and J. Grana (1998) "Ability to Pay and the Decision to Medicate," Medical Care 36, 202-211.

Tamblyn, Robyn, Rejean Laprise, James Hanley et al. (2001) "Adverse Events Associated with Prescription Drug Cost-Sharing Among Poor and Elderly Persons," Journal of the American Medical Association 285, 421-429.

Viscusi, W. Kip (1993) “The Value of Risks to Life and Health," Journal of Economic Literature XXXI, 1912-1946.

Viscusi, W. Kip and Joseph E. Aldy (2003) "The Value of a Statistical Life: A Critical Review of Market Estimates Throughout the World," Journal of Risk and Uncertainty 27, 5-76. 


\begin{tabular}{|c|c|c|c|c|c|c|}
\hline & \multicolumn{3}{|c|}{$\begin{array}{l}\text { Low Education Group: } \\
\text { Less than High School } \\
\qquad(\mathrm{N}=1755)\end{array}$} & \multicolumn{3}{|c|}{$\begin{array}{l}\text { High Education Group: } \\
\text { High School Diploma or More } \\
(\mathrm{N}=2252)\end{array}$} \\
\hline & $\begin{array}{c}\text { Mean } \\
\text { (Std. Dev.) }\end{array}$ & Min. & Max. & $\begin{array}{c}\text { Mean } \\
\text { (Std. Dev.) }\end{array}$ & Min. & Max. \\
\hline $\begin{array}{l}\text { Household } \\
\text { Prescriptions } \\
\text { (Usual number of } \\
\text { medications taken per } \\
\text { month) }\end{array}$ & $\begin{array}{c}4.01 \\
(3.00)\end{array}$ & 0.00 & 22.00 & $\begin{array}{c}3.85 \\
(2.92)\end{array}$ & 0.00 & 26.00 \\
\hline $\begin{array}{l}\text { Household Social } \\
\text { Security Income } \\
\text { (1993 dollars) }\end{array}$ & $\begin{array}{c}9625 \\
(4305)\end{array}$ & 1620 & 30,756 & $\begin{array}{l}11,085 \\
(5206)\end{array}$ & 1392 & 48,000 \\
\hline $\begin{array}{l}\text { Social Security } \\
\text { Beneficiary Born } \\
\text { Between 1915-1917 }\end{array}$ & $\begin{array}{c}0.18 \\
(0.39)\end{array}$ & 0.00 & 1.00 & $\begin{array}{c}0.18 \\
(0.39)\end{array}$ & 0.00 & 1.00 \\
\hline Head is a Single Male & $\begin{array}{c}0.13 \\
(0.34)\end{array}$ & 0.00 & 1.00 & $\begin{array}{c}0.10 \\
(0.31)\end{array}$ & 0.00 & 1.00 \\
\hline $\begin{array}{l}\text { Head is a Never- } \\
\text { Married Female }\end{array}$ & $\begin{array}{c}0.02 \\
(0.13)\end{array}$ & 0.00 & 1.00 & $\begin{array}{c}0.03 \\
(0.16)\end{array}$ & 0.00 & 1.00 \\
\hline $\begin{array}{l}\text { Head is a Female } \\
\text { Widow }\end{array}$ & $\begin{array}{c}0.36 \\
(0.48)\end{array}$ & 0.00 & 1.00 & $\begin{array}{c}0.34 \\
(0.47)\end{array}$ & 0.00 & 1.00 \\
\hline $\begin{array}{l}\text { Head is a Divorced } \\
\text { Female }\end{array}$ & $\begin{array}{c}0.03 \\
(0.16)\end{array}$ & 0.00 & 1.00 & $\begin{array}{c}0.03 \\
(0.17)\end{array}$ & 0.00 & 1.00 \\
\hline Age of Head & $\begin{array}{l}77.43 \\
(5.40)\end{array}$ & 63.00 & 93.00 & $\begin{array}{l}76.35 \\
(5.06)\end{array}$ & 64.00 & 92.00 \\
\hline $\begin{array}{l}\text { Head's Race is } \\
\text { African American }\end{array}$ & $\begin{array}{c}0.11 \\
(0.31)\end{array}$ & 0.00 & 1.00 & $\begin{array}{c}0.03 \\
(0.17)\end{array}$ & 0.00 & 1.00 \\
\hline Head's Race is Other & $\begin{array}{c}0.03 \\
(0.16)\end{array}$ & 0.00 & 1.00 & $\begin{array}{c}0.01 \\
(0.09)\end{array}$ & 0.00 & 1.00 \\
\hline $\begin{array}{l}\text { Head's Ethnicity is } \\
\text { Hispanic }\end{array}$ & $\begin{array}{c}0.08 \\
(0.27)\end{array}$ & 0.00 & 1.00 & $\begin{array}{c}0.02 \\
(0.14)\end{array}$ & 0.00 & 1.00 \\
\hline $\begin{array}{l}\text { Household is located } \\
\text { in a MSA }\end{array}$ & $\begin{array}{c}0.64 \\
(0.48)\end{array}$ & 0.00 & 1.00 & $\begin{array}{c}0.78 \\
(0.42)\end{array}$ & 0.00 & 1.00 \\
\hline
\end{tabular}

Notes: Summary statistics are weighted using the AHEAD household weights. The omitted category for the head-ofhousehold variable is married male. All regression models also contain indicators for the nine Census regions. 
Table 2. Effect of the Benefits Notch on Social Security Income by Educational Attainment

\begin{tabular}{|c|c|c|c|c|c|c|}
\hline & \multicolumn{3}{|c|}{$\begin{array}{l}\text { Low Education Group: } \\
\text { Less than High School }\end{array}$} & \multicolumn{3}{|c|}{$\begin{array}{l}\text { High Education Group: } \\
\text { High School Diploma or More }\end{array}$} \\
\hline & $\begin{array}{l}\text { Linear Age } \\
\text { Specification }\end{array}$ & $\begin{array}{l}\text { Quadratic Age } \\
\text { Specification }\end{array}$ & $\begin{array}{c}\text { Cubic Age } \\
\text { Specification }\end{array}$ & $\begin{array}{c}\text { Linear Age } \\
\text { Specification }\end{array}$ & $\begin{array}{l}\text { Quadratic Age } \\
\text { Specification }\end{array}$ & $\begin{array}{c}\text { Cubic Age } \\
\text { Specification }\end{array}$ \\
\hline $\begin{array}{l}\text { Notch Indicator - Effect } \\
\text { on household Social } \\
\text { Security income } \\
\text { (thousands of 1993dollars) }\end{array}$ & $\begin{array}{l}1.402 \\
(0.243) \\
{[0.000]}\end{array}$ & $\begin{array}{l}1.064 \\
(0.236) \\
{[0.000]}\end{array}$ & $\begin{array}{l}1.044 \\
(0.255) \\
{[0.000]}\end{array}$ & $\begin{array}{l}0.301 \\
(0.423) \\
{[0.482]}\end{array}$ & $\begin{array}{c}0.072 \\
(0.432) \\
{[0.869]}\end{array}$ & $\begin{array}{l}0.116 \\
(0.440) \\
{[0.794]}\end{array}$ \\
\hline R-Squared & 0.434 & 0.443 & 0.443 & 0.321 & 0.322 & 0.323 \\
\hline $\mathrm{N}$ & 1755 & 1755 & 1755 & 2252 & 2252 & 2252 \\
\hline $\begin{array}{l}\text { F-Statistic on Notch } \\
\text { Indicator }\end{array}$ & 33.18 & 20.40 & 16.80 & 0.51 & 0.03 & 0.07 \\
\hline $\begin{array}{l}\text { Notes: The dependent variable } \\
\text { head of the household was bor } \\
\text { also include controls for the ty } \\
\text { and female head - divorced), r } \\
\text { and region (indicators for eac } \\
\text { adiusted for clustering on birth }\end{array}$ & $\begin{array}{l}\text { al household S } \\
5,1916 \text {, or 191 } \\
\text { usehold (male } 1 \\
\text { e head (white, } \\
\text { nine Census r } \\
\text { displaved in p }\end{array}$ & $\begin{array}{l}\text { al Security incom } \\
\text { and "zero" otheru } \\
1-\text { married or coh } \\
\text { can American, or } \\
\text { ons). All regressi } \\
\text { ntheses: p-values }\end{array}$ & $\begin{array}{l}\text { measured in tho } \\
\text { e. The age varial } \\
\text { oiting; male head } \\
\text { ther), Hispanic e } \\
\text { as are weighted } \\
\text { e displaved in bre }\end{array}$ & $\begin{array}{l}1993 \text { dollars. } \\
\text { n each specific } \\
\text { female head - } 1 \\
\text { f the head, whet } \\
\text { AHEAD hous }\end{array}$ & $\begin{array}{l}\text { notch indicator } \\
\text { on is the age of th } \\
\text { er-married; femal } \\
\text { the household is } \\
\text { ld weights. Robu }\end{array}$ & $\begin{array}{l}\text { uals "one" if the } \\
\text { head. All models } \\
\text { head - widowed; } \\
\text { cated in a MSA, } \\
\text { standard errors, }\end{array}$ \\
\hline
\end{tabular}


Table 3. Effect of Social Security Income on Number of Prescriptions: Baseline Estimates

\begin{tabular}{|c|c|c|c|c|c|c|}
\hline & \multicolumn{2}{|c|}{$\begin{array}{l}\text { Linear Age } \\
\text { Specification }\end{array}$} & \multicolumn{2}{|c|}{$\begin{array}{l}\text { Quadratic Age } \\
\text { Specification }\end{array}$} & \multicolumn{2}{|c|}{$\begin{array}{c}\text { Cubic Age } \\
\text { Specification }\end{array}$} \\
\hline & OLS & IV & OLS & IV & OLS & IV \\
\hline $\begin{array}{l}\text { Household Social Security } \\
\text { Income } \\
\text { (thousands of } 1993 \text { dollars) }\end{array}$ & $\begin{array}{c}0.013 \\
(0.026) \\
{[0.626]}\end{array}$ & $\begin{array}{l}0.489 \\
(0.129) \\
{[0.001]}\end{array}$ & $\begin{array}{c}0.003 \\
(0.024) \\
{[0.896]}\end{array}$ & $\begin{array}{c}0.552 \\
(0.174) \\
{[0.004]}\end{array}$ & $\begin{array}{c}0.003 \\
(0.024) \\
{[0.903]}\end{array}$ & $\begin{array}{c}0.583 \\
(0.203) \\
{[0.008]}\end{array}$ \\
\hline Elasticity & 0.03 & 1.17 & 0.01 & 1.32 & 0.01 & 1.40 \\
\hline R-Squared & 0.138 & -- & 0.142 & -- & 0.142 & -- \\
\hline $\mathrm{N}$ & 1755 & 1755 & 1755 & 1755 & 1755 & 1755 \\
\hline \multicolumn{7}{|l|}{ First-Stage Regression } \\
\hline $\begin{array}{l}\text { Notch Indicator - Effect of } \\
\text { benefits notch on household } \\
\text { Social Security income } \\
\text { (thousands of 1993dollars) }\end{array}$ & -- & $\begin{array}{l}1.402 \\
(0.243) \\
{[0.000]}\end{array}$ & -- & $\begin{array}{c}1.064 \\
(0.236) \\
{[0.000]}\end{array}$ & -- & $\begin{array}{c}1.044 \\
(0.255) \\
{[0.000]}\end{array}$ \\
\hline F-Statistic on Instrument & -- & 33.18 & -- & 20.40 & -- & 16.80 \\
\hline
\end{tabular}


Table 4. Reduced Form Relationship Between the Benefits Notch and Prescription Drug Use

\begin{tabular}{|c|c|c|c|}
\hline & $\begin{array}{c}\text { Linear Age } \\
\text { Specification }\end{array}$ & $\begin{array}{l}\text { Quadratic Age } \\
\text { Specification }\end{array}$ & $\begin{array}{c}\text { Cubic Age } \\
\text { Specification }\end{array}$ \\
\hline $\begin{array}{l}\text { Notch Indicator - Effect of } \\
\text { benefits notch on number of } \\
\text { prescriptions }\end{array}$ & $\begin{array}{c}0.686 \\
(0.180) \\
{[0.001]}\end{array}$ & $\begin{array}{c}0.588 \\
(0.182) \\
{[0.003]}\end{array}$ & $\begin{array}{c}0.609 \\
(0.193) \\
{[0.004]}\end{array}$ \\
\hline R-Squared & 0.145 & 0.147 & 0.147 \\
\hline $\mathrm{N}$ & 1755 & 1755 & 1755 \\
\hline
\end{tabular}

Notes: The dependent variable is the usual number of prescription medications taken per month by the respondent and their spouse. All regressions include the controls listed at the bottom of Table 3 and are weighted using the AHEAD household weights. Robust standard errors, adjusted for clustering on birth year, are displayed in parentheses; p-values are displayed in brackets. 
Table 5. Excluding Households Headed By Widows and Divorced Females

\begin{tabular}{|c|c|c|c|c|c|c|}
\hline & \multicolumn{2}{|c|}{$\begin{array}{c}\text { Linear Age } \\
\text { Specification }\end{array}$} & \multicolumn{2}{|c|}{$\begin{array}{l}\text { Quadratic Age } \\
\text { Specification }\end{array}$} & \multicolumn{2}{|c|}{$\begin{array}{c}\text { Cubic Age } \\
\text { Specification }\end{array}$} \\
\hline & OLS & IV & OLS & IV & OLS & IV \\
\hline $\begin{array}{l}\text { Household Social Security } \\
\text { Income } \\
\text { (thousands of } 1993 \text { dollars) }\end{array}$ & $\begin{array}{c}0.029 \\
(0.030) \\
{[0.342]}\end{array}$ & $\begin{array}{l}0.436 \\
(0.132) \\
{[0.002]}\end{array}$ & $\begin{array}{l}0.016 \\
(0.028) \\
{[0.571]}\end{array}$ & $\begin{array}{l}0.437 \\
(0.181) \\
{[0.022]}\end{array}$ & $\begin{array}{l}0.016 \\
(0.028) \\
{[0.571]}\end{array}$ & $\begin{array}{c}0.443 \\
(0.187) \\
{[0.025]}\end{array}$ \\
\hline Elasticity & 0.07 & 1.06 & 0.04 & 1.06 & 0.04 & 1.07 \\
\hline R-Squared & 0.092 & -- & 0.099 & -- & 0.099 & -- \\
\hline $\mathrm{N}$ & 1069 & 1069 & 1069 & 1069 & 1069 & 1069 \\
\hline First-Stage Regression & & & & & & \\
\hline $\begin{array}{l}\text { Notch Indicator - Effect of } \\
\text { benefits notch on household } \\
\text { Social Security income } \\
\text { (thousands of 1993dollars) }\end{array}$ & -- & $\begin{array}{l}2.214 \\
(0.465) \\
{[0.000]}\end{array}$ & -- & $\begin{array}{l}1.821 \\
(0.481) \\
{[0.001]}\end{array}$ & -- & $\begin{array}{l}1.808 \\
(0.486) \\
{[0.001]}\end{array}$ \\
\hline F-Statistic on Instrument & -- & 22.67 & -- & 14.35 & -- & 13.82 \\
\hline
\end{tabular}


Table 6. Excluding Cohorts Born During the 1918 Flu Epidemic: Birth Cohorts 1918 and 1919

\begin{tabular}{|c|c|c|c|c|c|c|}
\hline & \multicolumn{2}{|c|}{$\begin{array}{c}\text { Linear Age } \\
\text { Specification }\end{array}$} & \multicolumn{2}{|c|}{$\begin{array}{l}\text { Quadratic Age } \\
\text { Specification }\end{array}$} & \multicolumn{2}{|c|}{$\begin{array}{c}\text { Cubic Age } \\
\text { Specification }\end{array}$} \\
\hline & OLS & IV & OLS & IV & OLS & IV \\
\hline $\begin{array}{l}\text { Household Social Security } \\
\text { Income } \\
\text { (thousands of } 1993 \text { dollars) }\end{array}$ & $\begin{array}{c}0.020 \\
(0.026) \\
{[0.458]}\end{array}$ & $\begin{array}{c}0.455 \\
(0.136) \\
{[0.002]}\end{array}$ & $\begin{array}{c}0.008 \\
(0.025) \\
{[0.750]}\end{array}$ & $\begin{array}{l}0.497 \\
(0.181) \\
{[0.011]}\end{array}$ & $\begin{array}{c}0.007 \\
(0.024) \\
{[0.767]}\end{array}$ & $\begin{array}{c}0.518 \\
(0.232) \\
{[0.034]}\end{array}$ \\
\hline Elasticity & 0.05 & 1.08 & 0.02 & 1.18 & 0.02 & 1.23 \\
\hline R-Squared & 0.138 & -- & 0.143 & -- & 0.143 & -- \\
\hline $\mathrm{N}$ & 1534 & 1534 & 1534 & 1534 & 1534 & 1534 \\
\hline First-Stage Regression & & & & & & \\
\hline $\begin{array}{l}\text { Notch Indicator - Effect of } \\
\text { benefits notch on household } \\
\text { Social Security income } \\
\text { (thousands of 1993dollars) }\end{array}$ & -- & $\begin{array}{l}1.457 \\
(0.273) \\
{[0.000]}\end{array}$ & -- & $\begin{array}{l}1.084 \\
(0.253) \\
{[0.000]}\end{array}$ & -- & $\begin{array}{l}1.065 \\
(0.298) \\
{[0.001]}\end{array}$ \\
\hline F-Statistic on Instrument & -- & 28.49 & -- & 18.33 & -- & 12.74 \\
\hline
\end{tabular}


Table 7. Utilizing A Narrower Range of Birth Cohorts: 1910 - 1920

\begin{tabular}{|c|c|c|c|c|c|c|}
\hline & \multicolumn{2}{|c|}{$\begin{array}{c}\text { Linear Age } \\
\text { Specification }\end{array}$} & \multicolumn{2}{|c|}{$\begin{array}{l}\text { Quadratic Age } \\
\text { Specification }\end{array}$} & \multicolumn{2}{|c|}{$\begin{array}{c}\text { Cubic Age } \\
\text { Specification }\end{array}$} \\
\hline & OLS & IV & OLS & IV & OLS & IV \\
\hline $\begin{array}{l}\text { Household Social Security } \\
\text { Income } \\
\text { (thousands of } 1993 \text { dollars) }\end{array}$ & $\begin{array}{c}0.007 \\
(0.034) \\
{[0.848]}\end{array}$ & $\begin{array}{l}0.507 \\
(0.143) \\
{[0.005]}\end{array}$ & $\begin{array}{c}0.003 \\
(0.030) \\
{[0.931]}\end{array}$ & $\begin{array}{l}0.606 \\
(0.225) \\
{[0.022]}\end{array}$ & $\begin{array}{c}0.002 \\
(0.031) \\
{[0.961]}\end{array}$ & $\begin{array}{c}0.586 \\
(0.222) \\
{[0.025]}\end{array}$ \\
\hline Elasticity & 0.02 & 1.24 & 0.01 & 1.48 & 0.00 & 1.43 \\
\hline R-Squared & 0.191 & -- & 0.192 & -- & 0.192 & -- \\
\hline $\mathrm{N}$ & 1062 & 1062 & 1062 & 1062 & 1062 & 1062 \\
\hline First-Stage Regression & & & & & & \\
\hline $\begin{array}{l}\text { Notch Indicator - Effect of } \\
\text { benefits notch on household } \\
\text { Social Security income } \\
\text { (thousands of 1993dollars) }\end{array}$ & -- & $\begin{array}{l}1.202 \\
(0.236) \\
{[0.000]}\end{array}$ & -- & $\begin{array}{l}1.000 \\
(0.246) \\
{[0.002]}\end{array}$ & -- & $\begin{array}{c}1.072 \\
(0.261) \\
{[0.002]}\end{array}$ \\
\hline F-Statistic on Instrument & -- & 26.00 & -- & 16.49 & -- & 16.89 \\
\hline
\end{tabular}


Table 8. Synthetic Benefits Instrument

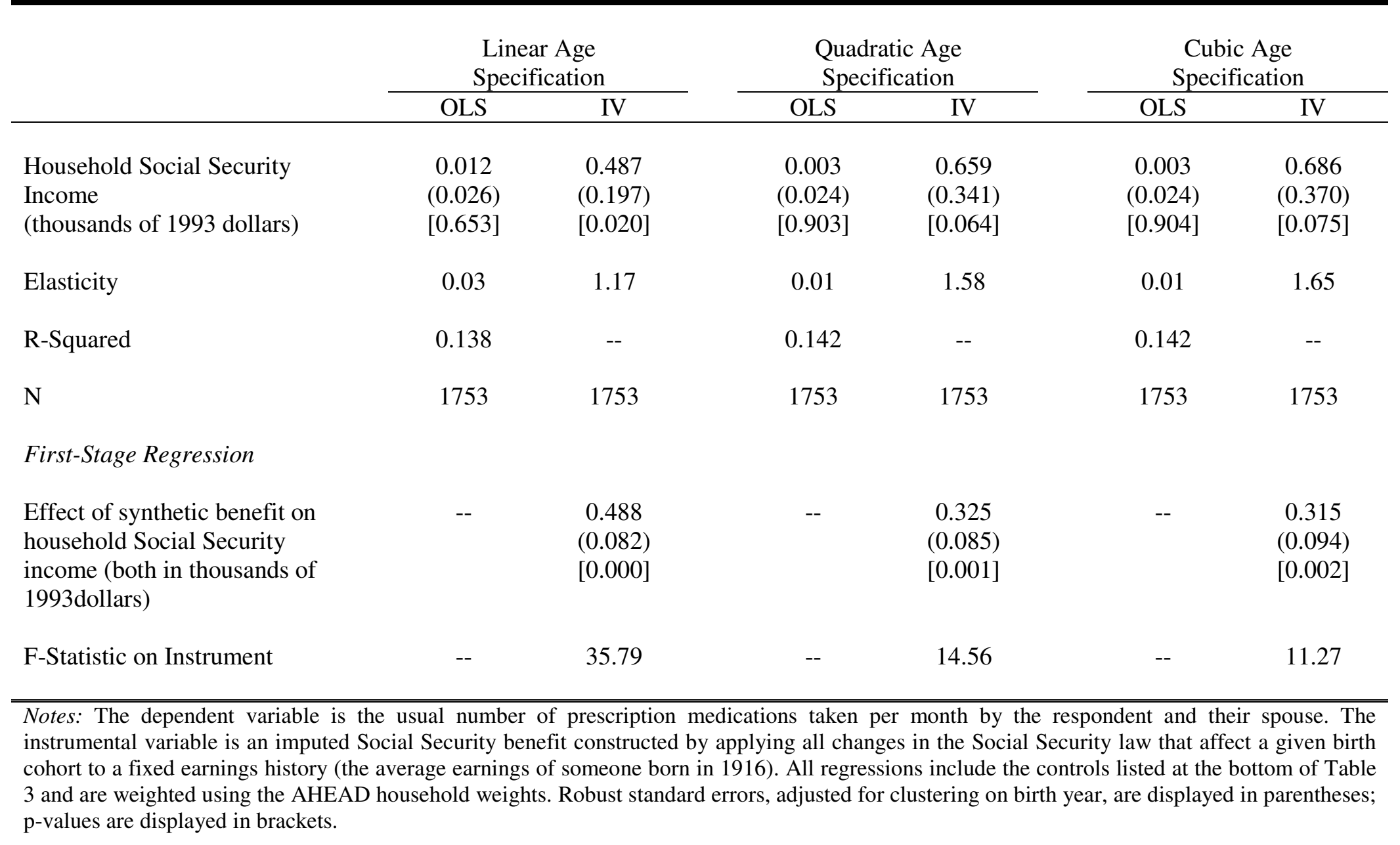


Table 9. Count Model / Log-Linear Specification

\begin{tabular}{|c|c|c|c|c|c|c|}
\hline & \multicolumn{2}{|c|}{$\begin{array}{c}\text { Linear Age } \\
\text { Specification }\end{array}$} & \multicolumn{2}{|c|}{$\begin{array}{l}\text { Quadratic Age } \\
\text { Specification }\end{array}$} & \multicolumn{2}{|c|}{$\begin{array}{c}\text { Cubic Age } \\
\text { Specification }\end{array}$} \\
\hline & Poisson & $\begin{array}{l}\text { Log-Linear } \\
\text { IV }\end{array}$ & Poisson & $\begin{array}{c}\text { Log-Linear } \\
\text { IV }\end{array}$ & Poisson & $\begin{array}{c}\text { Log-Linear } \\
\text { IV }\end{array}$ \\
\hline $\begin{array}{l}\text { Household Social Security } \\
\text { Income } \\
\text { (thousands of } 1993 \text { dollars) }\end{array}$ & $\begin{array}{l}0.003 \\
(0.006) \\
{[0.623]}\end{array}$ & $\begin{array}{l}0.105 \\
(0.025) \\
{[0.000]}\end{array}$ & $\begin{array}{c}0.001 \\
(0.005) \\
{[0.933]}\end{array}$ & $\begin{array}{c}0.114 \\
(0.034) \\
{[0.002]}\end{array}$ & $\begin{array}{c}0.001 \\
(0.005) \\
{[0.935]}\end{array}$ & $\begin{array}{c}0.118 \\
(0.040) \\
{[0.006]}\end{array}$ \\
\hline Elasticity & 0.03 & 0.97 & 0.01 & 1.06 & 0.01 & 1.09 \\
\hline $\mathrm{N}$ & 1755 & 1695 & 1755 & 1695 & 1755 & 1695 \\
\hline First-Stage Regression & & & & & & \\
\hline $\begin{array}{l}\text { Notch Indicator - Effect of } \\
\text { benefits notch on household } \\
\text { Social Security income } \\
\text { (thousands of 1993dollars) }\end{array}$ & -- & $\begin{array}{l}1.450 \\
(0.241) \\
{[0.000]}\end{array}$ & -- & $\begin{array}{l}1.122 \\
(0.236) \\
{[0.000]}\end{array}$ & -- & $\begin{array}{l}1.109 \\
(0.255) \\
{[0.000]}\end{array}$ \\
\hline F-Statistic on Instrument & -- & 36.10 & -- & 22.67 & -- & 18.95 \\
\hline
\end{tabular}




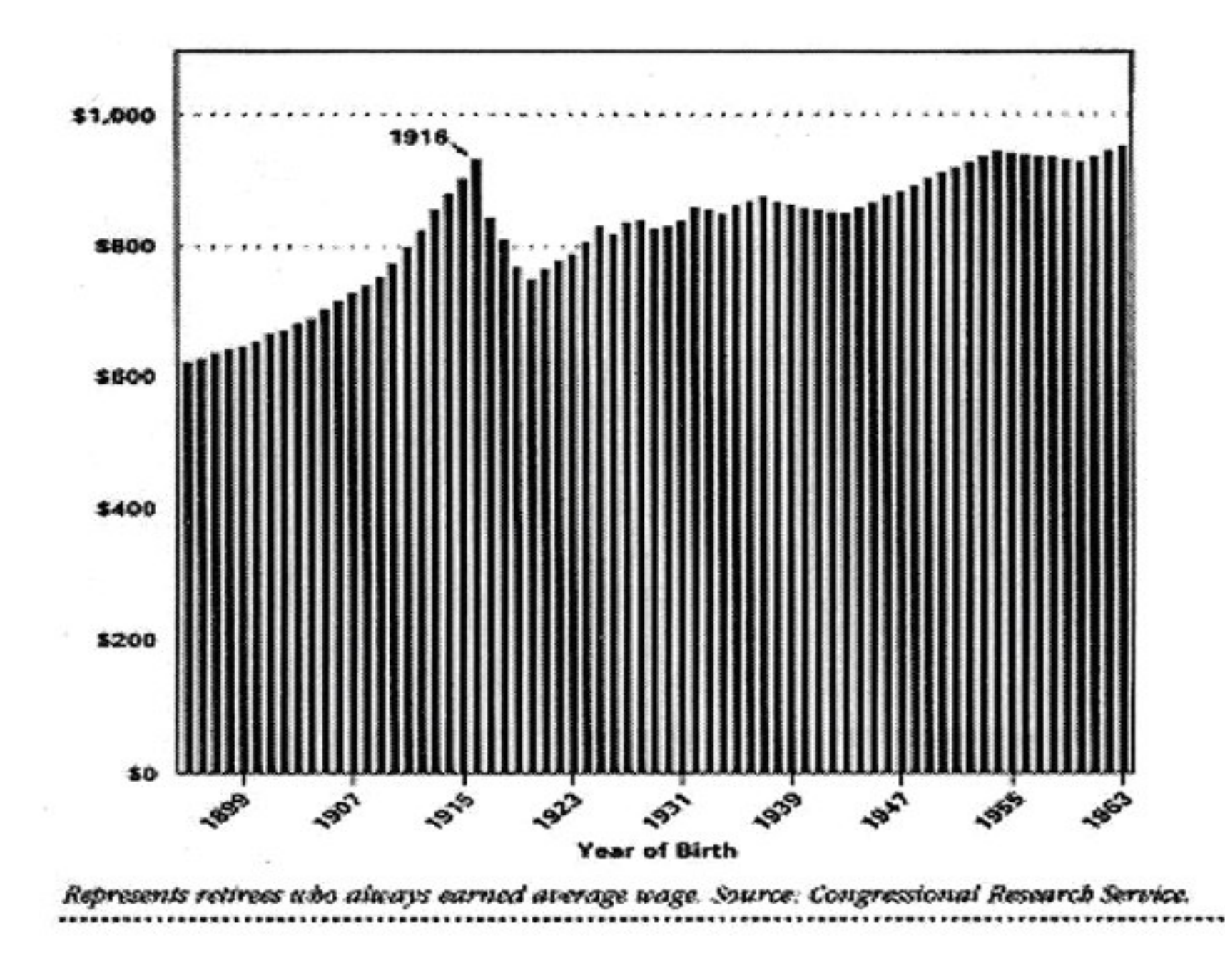

nami 
${ }^{1}$ The fraction is higher for low-income seniors, with health spending accounting for almost one third of income among retirees in the lowest quintile of the income distribution (Crystal et al., 2000).

${ }^{2}$ Future reductions in Social Security benefits, or large increases in Medicare premiums, could exacerbate the difficulties seniors face in obtaining prescription medications, or in adhering to costly drug regimens. A consensus has emerged that the impending retirement of the "baby-boom" cohorts will pose a significant challenge to the actuarial integrity of the Social Security system. This recognition has led to many reform proposals, a number of which advocate benefit reductions as a means of repairing the imbalance between revenues and benefit payments that will exist if payroll taxes are maintained at current levels. In remarks made at a central bank conference in Jackson Hole, Wyoming last August, Alan Greenspan asserted that, "If we have promised more than our economy has the ability to deliver to retirees without unduly diminishing real income gains of workers, as I fear we may have, we must recalibrate our public programs so that pending retirees have time to adjust through other channels."

(http://quote.bloomberg.com/apps/news?pid=10000006\&sid=aisrnMByOf4A\&refer=home). Recently, President Bush ruled out any increase in payroll taxes in discussing options for reforming the Social Security system.

(http://money.cnn.com/2004/12/09/news/bush_socsec/index.htm?cnn=yes).

${ }^{3}$ Concerns about the affordability of prescription drugs will be addressed, in part, by the recently enacted Medicare Prescription Drug Improvement and Modernization Act of 2003 (scheduled to take effect in 2006), but income will still be an important factor in determining drug utilization for many Americans due to the incomplete nature of the coverage provided by the Medicare drug benefit. Most retirees will face a $\$ 250$ annual deductible, a $25 \%$ coinsurance rate on their first $\$ 2250$ of drug expenses, and no coverage for prescription expenses between $\$ 2250$ and $\$ 5100$ (corresponding to $\$ 3600$ in out-of-pocket spending), with a $5 \%$ coinsurance rate being applied to expenditures above $\$ 5100$. Factoring in premiums of $\$ 420$ per year, the total costs of acquiring prescription medicines through the drug benefit will, for many, be quite large, leaving considerable scope for income effects.

A series of examples, taken from Altman (2004), are illustrative: "Under the new law, a relatively healthy 65 -year-old man with hypertension who now spends $\$ 730$ per year filling his brand-name prescription at his local pharmacy would spend a total of $\$ 790$ per year, including premiums $(\$ 420)$, the deductible $(\$ 250)$, and coinsurance. Thus, he would spend more in premiums and cost sharing than his drugs actually cost. During the same year, a 79year-old woman with multiple chronic (but common) conditions, including a history of congestive heart failure, hypertension, chronic arthritic pain, and Parkinson's disease, who takes nine different generic and brand-name medicines costing about $\$ 4,600$ per year would pay $\$ 3,520$ in premiums, deductibles, and cost sharing; she would fall into the doughnut hole. At the high end, a beneficiary with drug costs of $\$ 8,000$ would end up paying just over $\$ 4,100$ in premiums, deductibles, and cost sharing. The new benefit is structured to provide substantial relief to persons with catastrophic expenses of $\$ 5,100$ or more. Nearly one fifth of beneficiaries are projected to have costs at this level or higher in 2006."

An additional feature of the MMA, which has received little attention to date, is the indexing of the costsharing thresholds, many of which are expected to rise more rapidly than inflation. For example, the initial $\$ 3600$ stop-loss is scheduled to rise to $\$ 6400$ in the year 2013, a cumulative increase of 78 percent over seven years (see Altman, 2004 for details). And, although assistance will be available for people with "low incomes and limited assets," calculations reported later in the paper suggest that a substantial fraction of the lower-income households that we focus on would be exposed to these cost-sharing provisions.

There is also considerable uncertainty regarding the extent to which the Act's employer subsidies will prevent the new drug benefit from crowding out coverage provided through employer-sponsored retiree health insurance plans. If significant crowd-out were to occur, many retirees may not experience a meaningful increase in the generosity of their drug coverage. Finally, given that Medicare is on an even weaker fiscal footing than Social Security (2004 Annual Report of the Board of Trustees of the Federal Old-Age and Survivors Insurance and Disability Insurance Trust Funds, available online at:

http://www.ssa.gov/OACT/TR/TR04/index.html), it is possible that the drug benefit will eventually be scaled back, or that Medicare premiums will be increased. Thus, understanding the extent to which the drug benefit shields elderly households from income-induced changes in medication use will be important for assessing the desirability of this costly addition to the Medicare program. 
${ }^{4}$ This hypothesis has been advanced by Fuchs (1982) and has received support from a large literature that documents higher mortality rates and worse health habits among those with low educational attainment (Kenkel, 1991; Evans, Ringel and Stech, 1999).

${ }^{5}$ The positive relationship between job risk and earnings has been documented in numerous studies that use hedonic wage regressions to estimate the value of a statistical life. Viscusi (1993) and Viscusi and Aldy (2003) provide comprehensive reviews of this literature.

${ }^{6}$ We use Social Security income in our analysis, rather than total income, for two reasons. First, a substantial number of respondents in the AHEAD were unable to accurately report their total income. This was much less of a problem for Social Security income, which respondents were able to report on a monthly basis (i.e., the amount they receive in their monthly check). Second, the notch may have led to other behavioral changes that affected total income, e.g. a change in post-retirement work (Snyder and Evans, 2002), that would appear to offset the permanent increase in wealth created by the notch if total income were used in our regressions.

${ }^{7}$ For reasons discussed later, the increase in Social Security benefits associated with the notch was significantly larger for lower-income workers than for higher-income workers, yielding a better first-stage relationship for the former than for the latter. Following Engelhardt, Gruber and Perry (forthcoming), we split the sample based on educational attainment, rather than income, because income is directly affected by the notch. Using a similar split based on education, they did not find a statistically significant relationship between notch-induced changes in Social Security income and elderly living arrangements for more-educated retirees but, like us, did find a significant effect for retirees with less education.

${ }^{8}$ Our summary borrows heavily from these articles.

${ }^{9}$ Workers who had already retired had their Social Security payments indexed to the CPI, but did not benefit from double indexation because no adjustment was made to their AME.

${ }^{10}$ A set of transition rules was established to blunt the sharp reduction in payments to those born after 1916, but these "transitional guarantees" were not sufficient to prevent large differences in real benefits from developing across the affected cohorts.

${ }^{11}$ As noted by Snyder and Evans (2002), it is probably more natural to view those who received abnormally high benefits due to double indexation as being the "treatment" group, with those whose benefits were reduced back to a level in line with longer-run trends as being the "control" group.

${ }^{12}$ Figure 1 is from the Congressional Research Services Final Report on the Social Security "Notch" Issue. The Commission on the Social Security "Notch" Issue, December 31, 1994. The report is available online at: http://www.ssa.gov/history/notchbase.html.

${ }^{13}$ Given their ad hoc character, the legislated changes in benefits prior to 1972 were largely unpredictable, as must have been the error which led to double indexation. One might argue that the ensuing reduction in benefits created by the 1977 Amendments could have been anticipated, but this does not seem to have been the case. As Snyder and Evans (2002) note, it was actually the interaction between double indexation and the accelerating inflation of the 1970s that made the initial mistake so costly, and which led Congress to abruptly modify the law in 1977 - a change which most accounts suggest went unnoticed until after the affected cohorts began to retire.

${ }^{14}$ Engelhardt and Gruber (2004) utilize a similar approach in studying the impact of Social Security on elderly poverty rates.

${ }^{15}$ The Medicare Current Beneficiary Survey satisfies these criteria as well, but must be purchased from the Centers for Medicare and Medicaid Services (CMS). 
${ }^{16}$ Because we only have a single source of exogenous variation in Social Security income to work with, we are unable to examine the relative contributions of supplemental health insurance and directly-purchased prescriptions to overall consumption.

${ }^{17}$ This group is comprised of a small number of married or cohabiting women whose partner wasn't interviewed, either directly or by proxy.

${ }^{18}$ The vast majority of married women in these birth cohorts qualified for benefits based on their husband's earnings history. See Snyder and Evans (2002) for a discussion and additional references.

${ }^{19}$ Three years is the median difference in spousal ages for widowed/divorced elderly as calculated by Engelhardt, Gruber and Perry (forthcoming) using the 1982 New Beneficiary Survey published by the Social Security Administration. As we demonstrate later, our estimates are largely unchanged if these households are excluded from the analysis.

${ }^{20}$ Results are very similar if households receiving less than $\$ 200$ per month in Social Security benefits are dropped, or if no households are dropped.

${ }^{21}$ The head-of-household designation we use is based on our own definition. The head of each household is the primary Social Security beneficiary for all households except those headed by a widowed or divorced female. In these cases, the primary Social Security beneficiary is the former husband, while the head of the household is the widowed or divorced female surveyed by the AHEAD.

${ }^{22} \mathrm{We}$ include controls for the type of household for the sole purpose of mechanically adjusting for differences in prescription use across households of different sizes.

${ }^{23}$ Nonetheless, we have re-estimated our baseline specifications including controls for health and insurance status, with little change in the results.

${ }^{24}$ Although the AHEAD does not provide information on the birth year of deceased or former husbands, it does provide data on their level of education. We use this variable to form the sample split depicted in Table 1.

${ }^{25}$ Results were also generally unchanged when age was entered as a quartic. Unfortunately, allowing this level of flexibility in the age variable induced a near singularity in the $\mathbf{X}$ matrix due to the high degree of collinearity among the age terms. This led the coefficient estimates to become unstable in some cases.

${ }^{26}$ Not surprisingly, the standard errors on the second-stage estimates for the high-education group are too large to permit any reasonable inference concerning the magnitude of the income effect for this group.

${ }^{27}$ To get a rough feel for how many households in our low-education (lower-income) sample would likely be subject to full cost-sharing under the new Medicare prescription drug benefit, we calculated total household income separately for single (55.7 percent) and married households (44.3 percent) in our estimation sample (relying on imputations in cases where respondents were unable to report their total income), and inflated the dollar amounts to 2004 dollars using the CPI inflation calculator from the BLS website (http://www.bls.gov/cpi/home.htm). Although the income and asset limits for waiving the premium and cost-sharing provisions of the drug benefit are not scheduled to be announced until 2005, some groups have projected that the income thresholds for full and partial waivers are likely to be set at 135 percent and 150 percent of the federal poverty line (FPL)

(http://www.medicareadvocacy.org/PrescDrugs_LowIncomeProvisionsof2003Act.htm).

In 2004, the federal poverty guidelines for one- and two-person households were $\$ 9,310$ and $\$ 12,490$, respectively, yielding 150\% FPL figures of \$13,965 and \$18,735 (http://aspe.hhs.gov/poverty/04poverty.shtml). Approximately 52 percent of the single households and 67 percent of the married households in our low-education sample have incomes that place them above the 150\% FPL thresholds, suggesting that roughly 59 percent of the low-education (lower-income) households in our sample would be exposed to the cost-sharing provisions cited in the Introduction, with a larger percentage, those with incomes between 135 percent and 150 percent of the FPL, facing partial cost sharing. In contrast to the federal poverty guidelines used by the department of Health and Human Services (HHS), 
the Census Bureau specifies lower FPL thresholds for those aged 65 and over, but has not updated their figures for 2004. If the Centers for Medicaid and Medicare Services use the Census Bureau thresholds, the percentage of households exposed to cost sharing will be slightly higher.

${ }^{28}$ Note that the Social Security income figure reported in Table 1 must be converted into thousands of dollars before performing the elasticity calculation.

${ }^{29} \mathrm{We}$ also re-estimated equation (1) for the high-education sample to determine if the additional variation provided by the EGP instrument would allow us to obtain estimates for the high-education group. Unfortunately, the firststage relationship was again too weak to generate credible estimates for this group.

${ }^{30}$ Available online at: http://www.bls.gov/cpi/home.htm .

${ }^{31}$ Assuming the drug benefit does not lead to significant crowd out of currently-available retiree health benefits or is not scaled back as Medicare's fiscal problems become more urgent. 